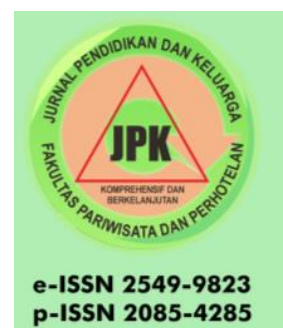

JURNAL PENDIDIKAN DAN KELUARGA

Vol. 11 No. 02, 2019 Page 146-155

DOI: https://doi.org/10.24036/jpk/vol11-iss02

available at http://jpk.ppj.unp.ac.id/index.php/jpk/index

\title{
PENGARUH KEPEMIMPINAN GENERAL MANAGER TERHADAP DISIPLIN KERJA KARYAWAN DI ROCKY PLAZA HOTEL PADANG
}

\author{
Aisyah $^{1}$ Hijriyantomi Suyuthie ${ }^{2}$ \\ Program Studi D4 Manajemen Perhotelan \\ Jurusan Pariwisata \\ FPP Universitas Negeri Padang \\ email: aisyahlailana19@gmail.com
}

Submitted: 2019-07-22

Accepted: 2019-11-03
Published: 2019-12-31

DOI: https://doi.org/10.24036/jpk/vol11-iss02/621

URL:http://jpk.ppj.unp.ac.id/index.php/ipk/article/view/621

\begin{abstract}
This research originated from the observations of researchers when doing the experience of the industrial field in Rocky Plaza Hotel Padang, ehere there are still problems with the work dicipline of employees and the leadership of the general manager. This study aims to determine the effect of general manager leadership on employee work dicipline in Rocky Plaza Hotel Padang. This type of research is quantitative with associative causal method. The study population was Rocky Plaza Hotel Padang employees totaling 54 people. The sampling technique in this study uses a non-probability sampling technique, while the type of non-probability used is proportionte stratified random sampling. The data in this study uses primary data for both variables obtained dirctly from employees through a questionnaire compiled based on the likert scale which has been tested for validity an reliability. data analysis technique in this study used regression test with the help of SPSS version 24.00. The results of the study show that: (1) the leadership of the general manager is in the good category of $50 \%$. (2) the work dicipline is in the good category of $50 \%$. (3) the results of the simple linear regression hypothesis test obtained F 15.605 with sig $0,000<0,05$. Then the general manager leadership variable can explain the varible work dicipline of employees at $23,1 \%$ and $76,9 \%$ influenced by other factors. Obtained t value of 3.950 with traf sig $0,000<0,05$. Then there is a significant influence between the two variabels. Then obtained a lnear regression coefficient of 0,517 with a sig value of $0,000<0,05$. meaning that every increase in a general manager leadership unit will increase 0.517 work dicipline of Rocky Plaza Hotel Padang.
\end{abstract}

Keywords: General Manager Leader, Work Dicipline, Employee

\begin{abstract}
Abstrak
Penelitian ini berawal dari pengamatan peneliti ketika melaksanakan kegiatan Pengalaman Lapangan Industri di Rocky Plaza Padang, dimana masih terdapatnya masalah-masalah mengenai disiplin kerja karyawan dan kepemimpinan general manager. Penelitian ini bertujuan untuk mengetahui pengaruh kepemimpinan general manager terhadap disiplin kerja karyawan di Rocky Plaza Hotel Padang. Jenis penelitian ini adalah kuantitatif dengan metode asosiatif kausal. Populasi penelitian ini adalah karyawan Rocky Plaza Hotel Padang yang berjumlah 54 orang. Teknik pengambilan sampel dalam penelitian ini menggunakan teknik non probability sampling, sedangkn jenis non probability sampling yang digunakan adalah proportionate stratified random sampling. Data dalam penelitian ini menggunakan data primer untuk kedua variabel

This is an open access article distributed under the Creative Commons 4.0 Attribution License, which permits unrestricted use, distribution, and reproduction in any medium, provided the original work is properly cited. $\odot 2017$ by author and Universitas Negeri Padang.


yang diperoleh langsung dari karyawan melalui kuisioner (angket) yang disusun berdasarkan skala likert yang telah diuji validitas dan reabilitasnya . teknik analisis data dalam penelitian ini menggunakan uji regresi dengan bantuan program SPSS versi 24.00. Hasil penelitian menunjukan bahwa: (1) Kepemimpinan general manager berada pada kategori baik 50\%, (2) Disiplin Kerja berada pada kategori baik yaitu 50\%, (3) hasil uji hipotesis regresi linear sederhana diperoleh F 15,605 dengan sig $0.000<0,05$, maka variabel kepemimpinan generl manager dapat menjelaskan variabel disiplin kerja karyawan sebesar $23,1 \%$ dan $76,9 \%$ dipengaruhi oleh faktor lainnya. Diperoleh nilai t sebesar 3.950 dengan taraf sig $0,000<0,05$. Maka terdapat pengaruh signifikan antara kedua variabel. kemudian diperoleh nilai koefisien regresi sebesar 0,517 dengan nilai sig.0,000<0,05. Artinya setiap peningkatan sebesar 1 satuan kepemimpinan general manager akan meningkatkan 0,517 disiplin kerja karyawan Rocky Plaza Hotel Padang.

Kata Kunci : Kepemimpinan General Manager, Disiplin Kerja, Karyawan

\section{Pendahuluan}

Pada era globalisasi saat ini perkembangan industri diberbagai bidang mengalami perkembangan yang sangat pesat, maka segala usaha dilakukan agar dapat memenangkan persaingan, demikian halnya dengan dunia pariwisata. Menurut Muljadi (2012 : 7),"Pariwisata adalah suatu aktifitas perubahan tempat tinggal sementara dari seseorang, diluar tempat tinggal sehari-hari dengan suatu alasan apapun selain melakukan kegiatan yang bisa menghasilkan upah atau gaji”. Pada saat ini indonesia sedang mengembangkan kepariwisataannya terutama di daerahdaerah wisata yang memiliki banyak potensi untuk menarik wisatawan yang dapat menambah devisa negara dan daerah, salah satunya adalah kota Padang.

Kota padang merupakan salah satu kota yang berada di Provinsi Sumatera Barat, dimana kota ini merupakan salah atu tujuan wisata yang diminati oleh wisatawan, selain terkenal dengan makanan khas tradisionalnya, kota ini juga terkenal dengan tempat wisata yang menarik yaitu Pantai Padang, Pantai Air Manis, Jembatan Siti Nurbaya dan Masjid Raya Sumatera Barat yang menjadi icon dari kota Padang. Potensi wisata yang menarik dari kota Padang, membuat industri pariwisata di daerah tersebut mendapat perhatian dari pemerintah dan membawa dampak positif bagi para pengusaha yang berminat untuk membangun usaha khususnya di industri perhotelan yaitu menyediakan penginapan bagi wisatawan yang datang berkunjung ke kota Padang.

Industri perhotelan tidak hanya menyediakan akomodasi penginapan tetapi juga menyediakan berbagai fasilitas penunjang lainnya. Menurut Sulastiyono (2001: 7), "Hotel adalah suatu jenis akomodasi yang menyediakan jasa penginapan, makan dan minuman serta jasa penunjang lainnya dan dikelola secara komersial". Hotel juga memerlukan adanya manajemen untuk mencapai tujuan yang diinginkan. Manajemen yang baik akan memudahkan terwujudnya tujuan perusahaan, karyawan dan tamu hotel. Salah satu bagian manajemen yang penting dalam sebuah hotel adalah sumber daya manusia. Menurut Hasibuan (2002 : 10), "Manajemen Sumber Daya manusia adalah ilmu dan seni yang mengatur hubungan dan peranan tenaga kerja efektif dan efisien membantu terwujudnya tujuan perusahaan, karyawan dan masyarakat".

Karyawan dituntut untuk mampu, cakap dan terampil dalam mengerjakan tugasnya. Selain itu tenaga kerja manusia juga harus mempunyai kemauan dan kesungguhan untuk bekerja efektif dan efisien. Mewujudkan kerja yang efektif dan efisien harus ditunjang dengan disiplin kerja sebagai salah satu faktor pendukungnya. Sutrisno (2009: 87) menerangkan bahwa, "Disiplin kerja ialah sikap hormat terhadap peraturan dan ketetapan perusahaan yang ada dalam diri karyawan yang menyebabkan ia dapat menyesuaikan diri dengan sukarela pada peraturan dan ketetapan perusahaan".

Pada hakekatnya disiplin akan tumbuh dan terpancar dari hasil kesadaran manusia. Disiplin yang tidak bersumber dari hati nurani manusia akan menghasilkan disiplin yang lemah dan tidak bertahan lama. Disiplin merupakan fungsi operatif manajemen sumber daya manusia yang terpenting, karena semakin disiplin karyawan, semakin tinggi prestasi yang dapat dicapai. Menurut Baskoro (2012 : 81) "terdapat empat dimensi dalam disiplin kerja yaitu tepat waktu menggunakan dan merawat perlatan kantor dengan baik, tanggung jawab dan menaati peraturan perusahaan". Beberapa contoh penerapan disiplin kerja seorang karyawan yaitu selalu datang dan pulang tepat pada waktunya, mengerjakan semua pekerjaanya dengan baik, mematuhi semua peraturan perusahaan dan norma-norma sosial yang berlaku. 


\section{Nova Shabrina ${ }^{1}$, Ira Meirina Chair ${ }^{2}$}

Menurut Hasibuan ( 2010 : 194), "Banyak indikator yang mempengaruhi tingkat kedisiplinan karyawan, diantaranya tujuan dan kemampuan, teladan pemimpin balas jasa, keadilan sanksi hukuman, ketegasan, hubungan kemanusiaan dan pengawas". Berdasarkan faktor-faktor yang mempengaruhi disiplin kerja tersebut, terlihat bahwa teladan pemimpin sangat penting dalam mencapai disiplin kerja yang baik. Stephen P. Robbins dalam Irham Fahmi (2018 : 2), mengatakan kepemimpinan adalah kemampuan untuk mempengaruhi suatu kelompok kearah tercapainya tujuan. menurut Renata dalam Isman Candra (2018) Indikator kepemimpinan yaitu pengambilan keputusan, motivator, partisipatif, menghargai masukan orang lain, dan membantu memperbaiki kinerja karyawan.

Berdasarkan hasil pra penelitian penulis pada bulan Juni-Juli 2019 rekapitulasi keterlambatan masuk kerja karyawanRocky Plaza Hotel Padang bulan Februari 2019 yaitu:

Table 1 Rekapitulasi keterlambatan masuk Kerja Karyawan Rocky Plaza Hotel Padang bulan Februari 2019

\begin{tabular}{cllcc}
\hline No & Dept & Jumlah Karyawan & $\begin{array}{c}\text { Jumlah } \\
\text { Keterlambatan }\end{array}$ & Persentase \\
\hline 1 & FO & 19 orang & 138 & $13,76 \%$ \\
\hline 2 & F \& B & 28 orang & 95 & $29,47 \%$ \\
\hline 3 & HK & 20 orang & 80 & $25 \%$ \\
\hline 4 & Eng & 10 orang & 37 & $27,02 \%$ \\
\hline 5 & Human Resourc & 15 orang & 45 & $33,3 \%$ \\
\hline 6 & Laundry & 4 orang & 25 & $16 \%$ \\
\hline 7 & S \&M & 4 orang & 15 & $26,67 \%$ \\
\hline 8 & Acc & 15 orang & 35 & $42,85 \%$ \\
\hline
\end{tabular}

Sumber : HRD Rocky Plaza Hotel Padang (2019)

Selama melaksanakan Pengalaman Lapangan Industri,selain melihat permasalahan disiplin penulis juga melihat adanya masalah terkait kepemimpinan General Manager. Berdasarkan wawancara penulis dengan beberapa orang karyawan mereka mengeluhkan masalah terkait kepemimpinan General Manager diantaranya General Manager kurang tegas dalam memberikan arahan dan masukan kepada karyawan yang melanggar aturan sehingga kesalahan yang sama terjadi berulang kali.

Selanjutnya masalah pengambilan keputusan yang terlihat dari General Manager tidak melibatkan karyawan dalam mengambil keputusan namun hanya melibatkan para manager saja sehingga karyawan tidak dapat memberikan pendapatnya. Selain itu juga teguran General Manager kurang ditanggapi oleh karyawan hal ini terlihat dari masih tingginya persentase keterlambatan karyawan.

Tujuan dari penelitian ini adalah untuk menganalisis pengaruh kepemimpinan general manager terhadap disiplin kerja karyawan di Rocky Plaza Hotel Padang ditinjau dari dua variable yaitu variabel X dengan indikator tepat waktu, menggunakan dan merawat peralatan kantor dengan baik, tanggung jawab dan mentaati peraturan perusahaan. dan variabel Y dengan 5 indikator yaitu : pengambilan keputusan, motivator, partisipatif, menuntut ketentuan penuh karyawan dan menghargai masukan orang.

\section{Metode Penelitian}

Jenis dari penelitian ini adalah penelitian yang bersifat kuantitatif dengan pendekatan asosiatif kausal. Populasi dari penelitian ini adalah seluruh karyawan di Rocky Plaza Hotel dengan jumlah 115 orang. Teknik pengambilan sampel adalah dengan teknik non probability sampling dan jenis non probability yang digunakan adalah proportionate stratified random sampling. Data dalam penelitian pengaruh kepemimpinan general manager terhadap disiplin kerja karyawan di Rocky Plaza Hotel Padang menggunakan data primer untuk variabel X dengan cara menyebar angket kepada 54 orang karyawan yang validitas dan reliabilitasnya sudah diuji dan data sekunder untuk variabel Y dengan cara meminta rekapitulasi keterlambatan masuk kerja karyawan kepada HRD Rocky Plaza Hotel Padang. Penelitian ini menggunakan rumus penelitian rata-rata ideal (Mi) dan standardeviasi (Sdi). Klarifikasi menurut Arikunto (2017) dapat dibagi menjadi 5 kategori yaitu: Kategori sangat baik 
$(\geq(\mathrm{Mi}+1,5 \mathrm{Sdi})$

Kategori baik

$(\mathrm{Mi}+0,5 \mathrm{Sdi})-<(\mathrm{Mi}+1,5 \mathrm{Sdi})$

Kategori kurang baik

$(\mathrm{Mi}-0,5 \mathrm{Sdi})-<(\mathrm{Mi}+0,5 \mathrm{Sdi})$

Kategori ridak baik

(Mi-1,5 Sdi)-< (Mi - 0,5 Sdi)

Kategori sangat tidak baik

$<(\mathrm{Mi}-1,5 \mathrm{Sdi})-$ kebawah

\section{Uji Reliabilitas}

Menurut Sugiyono (2012), "Suatu data dinyatakan reliabel apabila dua atau lebih peneliti dalam objek yang sama menghasilkan data yang sama, atau peneliti sama dalam waktu yang berbeda menghasilkan data yang sama, atau sekelompok data bila dipecah menjadi dua menunjukkan data yang tidak berbeda". Analisis realibilitas pada penelitian ini dilakukan dengan menggunakan program SPSS versi 24.00 dengan rumus analize $\rightarrow$ scale $\rightarrow$ reability analysis. Pengambilan keputusan untuk uji reabilitas merujuk pada kriteria yaiu jika suatu variabel reabilitasnya (Alpha Cronbach) $>0,6$ maka variabel tersebut dikatakan reliabel. (1) Jika suatu variabel nilai reliabilitasnya (Alpha Cronbach) $\geq 0,06$ maka variabel tersebut dikatakan reliabel. (2) Jika suatu variabel nilai reliabilitasnya (Alpha Cronbach) <0,06 maka variabel tersebut dikatakan tidak reliabel.

Dalam pengambilan keputusan untuk diuji reabitas adalah sebagai berikut: (1) Jika suatu variabel nilai reabilitasnya (Alpha Cronbach) $>0,6$ maka variabel tersebut dikatakan reliabel. (2) Jika suatu variabel nilai reabilitasnya (Alpha Cronbach) $<0,6$ maka variabel tersebut dikatakan tidak reliabel. Tingkat Reliabilitas instrumen digunakan skala seperti tabel dibawah ini:

Table 2 Interprestasi Nilai r (Alpha Cronbach)

\begin{tabular}{ll}
\hline Alpha Cronbach & Interprestasi \\
\hline $0,90-1,00$ & Sangat Tinggi \\
\hline $0,70-0,90$ & Tinggi \\
\hline $0,40-0,70$ & Sedang \\
\hline $0,20-0,40$ & Rendah \\
\hline $0,00-0,20$ & Sangat Rendah \\
\hline
\end{tabular}

Sumber: Sudjana (1989-118)

Table 3 Reliability Statistics Variabel Kepemimpinan

\begin{tabular}{ll}
\hline Cronbach's Alpha & N of Items \\
\hline .623 & 15 \\
\hline
\end{tabular}

Sumber: Hasil Olah Data (2019)

Terdapat niai reliabilitas variabel $\mathrm{X}$ kepemimpinan general Manager sebesar 0,623. Nilai reliabilitas kepemimpinan general manager tergolong sedang. Jika nilai reliabilitas $>0,6$ maka dikatakan reliabel.

Table 4 Reliability Statistics Variabel Disiplin Kerja

\begin{tabular}{ll}
\hline Cronbach's Alpha & N of Items \\
\hline .711 & 16 \\
\hline
\end{tabular}

Sumber: Hasil Olah Data (2019)

Terdapat nilai reliabilitas Y Disiplin Kerja sebesar 0,711. Nilai reliabilitas disiplin kerja tergolong tinggi. Jika nilai reliabilitas $>0,6$ maka dikatakan reliabel.

\section{Pengujian Hipotesis \\ Uji Regresi Linear Sederhana}

Uji regresi linear sederhana yang menyatakan seberapa jauh perubahan antara variabel $\mathrm{X}$ dan $\mathrm{Y}$ dengan menggunakan alat bantu komputer program SPSS versi 24.00, dengan menggunakan rumus: 


\section{Nova Shabrina ${ }^{1}$, Ira Meirina Chair ${ }^{2}$}

Keterangan:

Y:Subjek dalam variabel yang di prediksikan

a:Harga angka $\mathrm{Y}$ bila $\mathrm{X}=0$ (harga konstanta)

b:Angka arah koefisien yang menunjukkan arah peningkatan ataupun penurunan variable dependen yang didasarkan pada variabel independen. Bila b (+) maka naik, dan bila (-) maka terjadi penurunan.

X: Subjek pada variabel independen yang mempunyai nilai tertentu. Selanjutnya harga "a" dapat dihitung dengan menggunakan rumus

$$
a=\frac{\sum Y\left(\sum X^{2}\right)-\sum X\left(\sum X Y\right)}{n \sum X^{2}-\left(\sum X\right)^{2}}
$$

Sedangkan untuk harga " $b$ " dapat dihitung dengan menggunakan rumus:

$$
b=\frac{n \sum X_{i} Y_{i}-\left(\sum X\right)_{i}\left(\sum Y_{i}\right)}{n \sum X_{i}{ }^{2}-\sum\left(X_{i}\right)^{2}}
$$

Kriteria pengambilan keputusan adalah: (1) Jika nilai signifikan $<0,05$, maka kepemimpinan General Manager berpengaruh signifikan terhadap disiplin kerja karyawan, (22) Jika nilai signifikan $\geq 0,05$, maka kepemimpinan General Manager tidak berpengaruh signifikan terhadap disiplin kerja karyawan

\section{Hasil Penelitian Dan Pembahasan}

\section{Variabel kepemimpinan general manager $(X)$}

Data Variabel kepemimpinan general manager (X) dikumpulkan melalui pernyataan yang terdiri dari butir pernyataan (kuisioner) yang telah diuji validitas dan reliabilitasnya. Selanjutnya kuesioner disebarkan kepada 54 responden untuk dijawab. Berdasarkan data yang diperoleh dari hasil penelitian pada variabel kepemimpinan general manager di Rocky Plaza Hotel Padang sebagai berikut:

Table 5 Klasifikasi Skor Jawaban Responden Tentang Variabel Kepemimpinan general manager

\begin{tabular}{llll}
\hline Kategori & Rentang skor & F & Persentase \\
\hline Sangat Baik & $\geq 60$ & 20 & 37,03 \\
\hline Baik & $50-<60$ & 27 & 50 \\
\hline Cukup & $40-<50$ & 7 & 12,96 \\
\hline Buruk & $30-<40$ & 0 & 0 \\
\hline Sangat Buruk & $<30$ & 0 & 0 \\
\hline & & 54 & 100
\end{tabular}

Sumber : data sekunder yang telah diolah kembali (2019).

Berdasarkan pengkategorian skor dan nilai rata-rata pada statistik hasil penelitian, terlihat bahwa penilaian karyawan tentang kepemimpinan general manager sebesar 50 berada pada rentang 50-60 dengan kategori baik, Sehingga dapat disimpulkan bahwa penilaian karyawan tentang kepemimpinan general manager di rocky plaza Hotel Padang adalah baik

Variabel Disiplin Kerja Karyawan (Y)

Dalam penelitian ini data tentang disiplin kerj karyawan diperoleh dari menyebar kuesioner yang terdiri dari 16 pernyataan yang disebar ke 54 orang karyawan di Rocky Plaza Hotel Padang yang sebelumnya telah dilakukan pengujian validitas dan reliabilitasnya. Bersumber dari pengisian kuesioner maka dapat diperoleh deskripsi data sebagai berikut :

Table 6 Klasifikasi Skor Jawaban Responden Tentang Variabel Disiplin Kerja

\begin{tabular}{|c|c|c|}
\hline Kategori & Rentang Skor & $\mathrm{F}$ \\
\hline
\end{tabular}
Karyawan

This is an open access article distributed under the Creative Commons 4.0 Attribution License, which permits unrestricted use, distribution, and reproduction in any medium, provided the original work is properly cited. (C2017 by author and Universitas Negeri Padang. 


\begin{tabular}{llll}
\hline Sangat Baik & $>63,9$ & 21 & 38,8 \\
\hline Baik & $53,3-63,9$ & 27 & 50 \\
\hline Cukup & $42,7-53,3$ & 6 & 11,11 \\
\hline Buruk & $24-42,7$ & 0 & 0 \\
\hline Sangat Buruk & $<24$ & 0 & 0 \\
\hline Jumlah & & 54 & 100 \\
\hline
\end{tabular}

Sumber : Data sekunder yang telah diolah (2019)

Berdasarkan pengkategorian skor dan nilai rata-rata pada statistik hasil penelitian, terlihat bahwa penilaian tentang disiplin kerja karyawan sebesar 50 berada pada rentang > 53,3-63,9 dengan kategori baik. Sehingga dapat disimpulkan bahwa disiplin kerja karyawan Hotel Padang adalah baik. Uji Persyaratan Analisis Uji Normalitas

Pada Tabel 35 Uji Normalitas Diperoleh nilai Asymp. Sig. untuk Variabel kepemimpinan general manager adalah 0,720 dan Variabel disiplin kerja adalah 0,577. Dengan nilai signifikan > dari 0,05, maka dapat dikatakan bahwa keduadata terdistribusi normal.

Table 7 Uji Normalitas dengan One-Sample Kolmogorov-Smirnov Test

\begin{tabular}{llll}
\hline & & $\mathrm{X}$ & $\mathrm{Y}$ \\
\hline $\mathrm{N}$ & & 54 & 54 \\
\hline Normal Parameters $^{\mathrm{a}}$ & Mean & 57.20 & 63.24 \\
\cline { 2 - 4 } & Std. Deviation & 6.620 & 7.127 \\
\hline \multirow{2}{*}{$\begin{array}{l}\text { Most Extreme } \\
\text { Differences }\end{array}$} & Absolute & .095 & .106 \\
\cline { 2 - 4 } & Positive & .051 & .106 \\
\cline { 2 - 4 } & Negative & -.095 & -.103 \\
\hline Kolmogorov-Smirnov Z & & .695 & .780 \\
\hline Asymp. Sig. (2-tailed) & & .720 & .577 \\
\hline Sumber: Data primer yang & &
\end{tabular}

Sumber : Data primer yang telah diolah (2019)

Uji Homogenitas

Pada tabel 36 uji Homogenitas diperoleh nilai Sig. adalah 0,51 berarti > 0,05. Ini artinya nilai signifikansi data lebih besar dari taraf signifikansi, sehingga dapat diambil kesimpulan bahwa data berasal dari populasi yang mempunyai varians yang sama atau data bersifat homogen.

Table 8 Uji Homogenitas

\begin{tabular}{llll}
\hline Levene Statistic & df1 & df2 & Sig. \\
\hline 2.026 & 14 & 30 & .051 \\
\hline
\end{tabular}

Sumber : Data primer yang telah diolah (2019)

\section{Uji Linearitas}

Berdasarkan Tabel 37 hasil uji linearitas, diperoleh nilai sig. 0.666 dimana nilai tersebut besar dari 0,05, maka dapat disimpulkan terdapat hubungan yang linear secara signifikan antara variabel kepemimpinan general manager $(\mathrm{X})$ dengan disiplin kerja karyawan $(\mathrm{Y})$. 
Table 9 Uji Linearitas dengan Tabel ANOVA

\begin{tabular}{|c|c|c|c|c|c|c|c|c|}
\hline & & & & Sum of Squares & df & Mean Square & $\mathrm{F}$ & Sig. \\
\hline \multirow{5}{*}{$\begin{array}{l}\text { TY } \\
\text { TX }\end{array}$} & \multirow{3}{*}{$\begin{array}{l}\text { 'Between } \\
\text { Groups }\end{array}$} & (Combined) & & 1407.304 & 23 & 61.187 & 1.429 & .178 \\
\hline & & Linearity & & 621.350 & 1 & 621.350 & 14.511 & .001 \\
\hline & & $\begin{array}{l}\text { Deviation } \\
\text { Linearity }\end{array}$ & fron & 785.954 & 22 & 35.725 & .834 & .666 \\
\hline & \multicolumn{2}{|c|}{ Within Groups } & & 1284.567 & 30 & 42.819 & & \\
\hline & \multicolumn{2}{|l|}{ Total } & & 2691.870 & 53 & & & \\
\hline
\end{tabular}

Sumber : Data primer yang telah diolah (2019)

\section{Uji Hipotesis}

Uji Regresi Linear Sederhana

Uji Regresi Linear Sederhana dilakukan untuk mengetahui seberapa jauh pengaruh satu variable dengan variable yang lainnya. Hasil uji regresi linear sederhana dapat dilihat pada tabel berikut:

Table 10 R Square Variabel X terhadap Variabel Y

\begin{tabular}{llllll}
\hline Model & & $\mathrm{R}$ & $\mathrm{R}$ Square & Adjusted R Square & td. Error of the Estimat \\
\hline dimension! & 1 &, $480^{\mathrm{a}}$ &, 231 &, 216 & 6,310 \\
\hline a. Predictors: (Constant), kepemimpinan & & \\
\hline a. Predictors: (Constant), kepemimpinan & & \\
Sumber : Data primer yang telah diolah (2019)
\end{tabular}

Berdasarkan tabel 38 Koefisien Regresi Variabel X Terhadap Y diperoleh nilai R Square 0,231 Artinya pengaruh variable $\mathrm{X}$ terhadap variable $\mathrm{Y}$ adalah sebesar 0,231(23,1\%). Sedangkan 76,9\% dipengaruhi oleh faktor lain

Table 11 Hasil Uji Regresi Linear Sederhana dengan Tabel Anova

\begin{tabular}{lllllll}
\hline Model & & Sum of Squares & Df & Mean Square & F & Sig. \\
\hline \multirow{3}{*}{1} & Regression & 621,350 & 1 & 621,350 & 15,60 &, $000^{\mathrm{a}}$ \\
\cline { 2 - 7 } & Residual & 2070,520 & 52 & 39,818 & & \\
\cline { 2 - 7 } & Total & 2691,870 & 53 & & & \\
\hline
\end{tabular}

a. Predictors: (Constant), kepemimpinan

b. Dependent Variable: disiplin

Sumber : Data primer yang telah diolah (2019)

Selanjutnya berdasarkan hasil uji regresi linier diatas diperoleh nilai $F$ 15,6055 dengan sig. $0,000<0,05$ dan diperoleh nilai t 3.950 dengan taraf sig. $0,000<0,05$, artinya variabel kepemimpinan general manager mempengaruhi variable disiplin kerja karyawan secara signifikan, maka Ha diterima dan Ho ditolak. 
Table 12 Koefisien Regresi Variabel X Terhadap Y

\begin{tabular}{|c|c|c|c|c|c|}
\hline \multirow{2}{*}{ Model } & \multicolumn{2}{|c|}{ Unstandardized Coefficients } & \multirow{2}{*}{$\begin{array}{c}\text { Standardized } \\
\text { Coefficients } \\
\text { Beta }\end{array}$} & \multirow[t]{2}{*}{$\mathrm{T}$} & \multirow{2}{*}{ Sig. } \\
\hline & $\mathrm{B}$ & Std. Error & & & \\
\hline (Constant) & 33.654 & 7.539 & & 4.464 & .000 \\
\hline TX & .517 & .131 & .480 & 3.950 & .000 \\
\hline
\end{tabular}

a. Dependent Variable: TY

Sumber : Data primer yang telah diolah (2019)

Selanjutnya untuk mengetahui besar koefisien regresi antara variable kepemimpinan general manager $(\mathrm{X})$ terhadap disiplin kerja karyawan (Y).Maka dapat dilihat pada persamaan berikut.

$\mathrm{Y}=\mathrm{a}+\mathrm{bx}$

$\mathrm{Y}=33,654+517 \mathrm{X}$

Berdasarkan persamaan diatas diperoleh koefisien regresi sebesar 0,517dengan nilai sig. $0,000<0,05$. Artinya setiap peningkatan sebesar 1satuan kepemimpinan general manager akan meningkatkan 0,517 satuan disiplin kerja karyawan.

\section{Pembahasan}

\section{Kepemimpinan general manager $(X)$}

Berdasarkan hasil penelitian dapat dijelaskan bahwa jawaban 54 orang responden untuk variabel kepemimpinan general manager terdapat 50\% yang termasuk dalam kategori baik dengan rentang skor 50-60. Oleh karena itu, pihak manajemen harus lebih meningkatkan kepemimpinan general manager agar dapat meningkatkan kategori baik menjadi sangat baik.

\section{Disiplin kerja karyawan (Y)}

Berdasarkan hasil penelitian dapat dijelaskan bahwa 54 orang responden untuk variabel disiplin kerja karyawan terdapat sebanyak 50\% dengan rentang skor 53,3-63,9 termasuk dalam kategori baik. ada lima indikator dalam disiplin kerja karyawan yaitu waktu, menggunakan dan merawat peralatan kantor dengan baik, tanggung jawab dan mentaati peraturan perusahaan. Berdasarkan hasil dari setiap indikator dapat dilihat bahwa disiplin kerja karyawan di rocky plaza Hotel Padang secara keseluruhan masih termasuk kategori baik. Oleh karena itu pihak manajemen mempertahankan atau lebih meningkatkan kepemimpian general manager terhadap disiplin kerja karyawan. Arlinda (2016 : 2) menyatakan bahwa "Disiplin kerja adalah sikap hormat terhadap peraturan dan ketepatan perusahaan yang ada dalam diri karyawan yang menyebabkan ia dapat menyesuaikan diri dengan sukarela pada peraturan dan ketetapan perusahaan.

Pengaruh kepemimpinan general manager terhadap disiplin kerja karyawan di rocky plaza hotel padang

Berdasarkan hasil uji hipotesis yang dilakukan untuk mengetahui pengaruh antara Kepemimpinan General Manager Terhadap Disiplin Kerja Karyawan, maka didapat hasil persamaan koefisien regresi sebesar 0,517 dengan nilai sig. $0,000<0,05$. Artinya setiap peningkatan sebesar 1 satuan kepemimpinan general manager akan meningkatkan 0,517 disiplin kerja karyawan. Maka variable Kepemimpinan General Manager (X) secara signifikan berpengaruh terhadap variabel Disiplin Kerja Karyawan (Y). Kemudian diperoleh nilai R Square 0,231. Artinya pengaruh variabel X terhadap variable $Y$ adalah sebesar 0,231(23,1\%), Sedangkan 76,9\% dipengaruhi oleh faktor lainnya Maka hipotesis yang diterima dalam penelitian ini adalah Ha diterima dan $\mathrm{H} 0$ ditolak.

\section{Simpulan}

Kepemimpinan General Manager di Rocky Plaza Hotel Padang menunjukan secara keseluruhan termasuk dalam kategori baik dengan nilai persentase 50\%. Disiplin Kerja Karyawan di Rocky Plaza Hotel Padang mennjukan secara keseluruhan termasuk dalam kategori baik dengan nilai persentase 50\% Terdapat pengaruh yang signifikan antara kepemimpinn general manager terhadap disiplin kerja karyawan di Rocky Plaza Hotel Padang dengan koefisien regresi sebesar 0,517 dengan nilai sig.0,000<0,05. Artinya setiap peningkatan sebesar 1 satuan kepemimpinn general manager akan meningkatkan 0,517 disiplin kerja karyawan. Serta diperoleh koefisien determinan sebesar $(0,231) \quad 23,1 \%$ dan 76,9 \% dipengaruhi oleh faktor lainny dengan nilai R Squere sebesar 0,231. 


\section{Nova Shabrina ${ }^{1}$, Ira Meirina Chair ${ }^{2}$}

Adapun faktor lain tersebut seperti kemampuan, balas jasa, keadilan, pengawasan, ketegasan, hubungan kemanusiaan dan lain sebagainya.

\section{Saran}

Berdasarkan pembahasan kesimpulan yang diperoleh, maka dapat diberi saran sebagai berikut:

\section{Kepada Pihak Manajemen Rocky Plaza Hotel Padang}

Sebaiknya pihak manajemen hotel memberikan sosilisasi secara berkala mengenai tata tertib perusahaan agar karyawan tidak melakukan pelanggaran berulang kali. Memotivasi karyawna dengan memberikan reward kepada setiap karyawn yang dapat bekerja melebihi target dan waktu yang telah ditetapkan oleh perusahaan. Menciptakan hubungan yang harmonis dengan karyawan dengan mengadakan family gathering agar rasa lelah karyawan selama bekerja terobati. Sebaiknya general manager lebih tegas agar apa yang diperintahkan terlaksana untuk kepentingan organisasi dan general manager juga harus tegas dalam mengambilan keputusan serta selalu mengikut sertakan bawahan dalam mengambil keputusan.

\section{Kepada Karyawan}

Bagi karyawan disarankan untuk dapat hdir 15 menit sebelum jam masuk kerjs dimulai agar tidak ada lagi karyawa yang datang terlambat dan tidak terburu-buru ketika akan bekerja. Mematuhi peraturan yang telah ditetapkan atasan dlam bekerja sesuai dengan tata tertib perusahaan. Mematuhi setiap peraturan yang berlaku diperusahaan agar dapat mengembangkan potensi diri, meningkatkan sesuai dengan bidang pekerjaan.

\section{Jurusan Pariwisata}

Kepada Jurusan Pariwisata dan Perhotelan Universitas Negeri Padang disarankan agar dapat memberikan materi dan memperbanyak referensi mengenai kepemimpinan dan disiplin. Hal ini dikarenakan masih terbatasnya materi mengenai kepemimpinan dan disiplin tersebut.

\section{Kepada Peneliti lainnya}

Bagi peneliti berikutnya disarankan agar dapat mencari faktor lain yang dapat mempengaruhi disiplin kerja selain kepemimpinan. Hal ini dikarenakan masih terdapat banyak faktor lain yang mempengaruhi disiplin kerja seperti tujuan dan kemampuan, balas jasa, pengawasan, sanksi hukum, ketegasan, hubungan manusia dan lain sebagainya

\section{Daftar Pustaka}

A.J, Mulyadi. 2012. Kepariwisataan dan Perjalanan, Jakarta: Raja Grafindo Persada

Agus Sulastiyono, 2001. Manajemen Penyelenggaraan Hotel, Bandung: C.V. Alfabet

Arikunto, Suharsimi. 2006. Prosedur penelitian suatu pendekatan praktik edisi Revisi. Jakarta: Rineka Cipta

Arikunto, Suharsimi. 2010. Manajemen penelitian. Jakarta: RinekaCipta

Arlinda, Putri, Yuliana, Yulia, Suyuthie, Hijriyantomi 2016. Hubungan Pengawasan Supervisor dengan disiplin kerj karyawan housekeeping di Hotel Rocky Plaza Padang. Vol 11. No.1 http://ejournal.unp.ac.id (diakses pada tanggal 5 juli 2019

Hasibuan, Melayu, 2002. Manajemen Sumber daya manusia edisi revisi, Jakarta:Bumi Aksara

Hasibuan, Melayu. 2010. Manajemen Sumber daya manusia edisi revisi, Jakarta:Bumi Aksara

This is an open access article distributed under the Creative Commons 4.0 Attribution License, which permits unrestricted use, distribution, and reproduction in any medium, provided the original work is properly cited. (C2017 by author and Universitas Negeri Padang. 
Hasibuan, Melayu. 2012. Manajemen Sumber daya manusia edisi revisi, Jakarta:Bumi Aksara

Musanef.2008. Manajemen Kepegawaian Indonesia. Jakarta: Haji Masagung

Rivai. 2012. Kepemimpinan dan perilaku Organisasi. Edisi Ketiga. Jakarta: PT Rajagrafindo Persada

Rocky Plaza Hotel Padang, 2011.Buku Pegangan Karyawan

Rocky Plaza Hotel Padang, 2019. Data karyawan Rocky Plaza Hotel Padang Human Resources Departmen.

Sudjono, 2000, Dimensi dan Indikator Disiplin Kerja. Surabaya. SMMAS

Sugiyono, 2010.Metode penelitian administratif. Bandung: Alfabeta

Sugiyono. 2013.Metode penelitian pendidikan pendekatan kuantitatif, Kualitatif, dan R \& D. Bandung: Alfabeta

Sulastiyono, Agus. 2001. Manajemen Sumber daya manusia. Jakarta:

Bumi Aksara

Sutrisno, Edy.2009. Manajemen Sumber daya manusia. Jakarta: Kecana

Veithzal Rivai, 2004, “ Manajemen Sumber Daya Manusia Untuk Perusahaan Cetakan Pertama, Jakarta, PT.Raja Grafindo Persada. 